\title{
Alternativas a la elevación de seno maxilar: implantes cortos
}

\author{
Alternatives to maxillary sinus elevation: short implants
}

\section{J. González Lagunas}

Resumen: La mala calidad del hueso, reabsorciones extremas y la presencia de la cavidad del seno maxilar constituían obstáculos insalvables para la rehabilitación implanto-soportada en el sector posterior del maxilar atrófico. La elevación de seno es probablemente la primera opción de tratamiento en el paciente tributario de rehabilitación con implantes en ese sector. El uso de implantes cortos (menos de $10 \mathrm{~mm}$ ) se ha asociado tradicionalmente con unas tasas de supervivencia menores que la de los implantes largos. No obstante la aparición de nuevas superficies y diseños indican que este tipo de implantes puede soportar de forma fiable restauraciones dentales. Presentamos la técnica de instalación de implantes de superficie porosa sinterizada, asi como una revisión actualizada sobre el comportamiento de los implantes cortos

Palabras clave: Implantes dentales, Maxilar edéntulo, cirugíaa maxilar.

Recibido: 29.10 .08

Aceptado: 20.11.2008
Abstract: Poor bone quality, extreme bony resorption and a pneumatized mqxillary sinus are a severe Challenger for reconstruction of the atrophic edentuous posterior maxilla. Sinus lift is probably the gold standard for Management of that area. Short implants $(<10 \mathrm{~mm})$ have traditionally been associated with lower survival rates. The introduction of new surfaces and designs indicate that this type of implants can adequately support dental restorations. We present the technique of installation of sinterised porous dental implants together with an update on the behaviour of short implants.

Key words: Dental implants, Tooth loss, maxillary surgery.

Servicio de Cirugía Oral y Maxilofacial e Implantología.

Hospital Quirón, Barcelona.España

\section{Correspondencia:}

Dr. Javier González Lagunas

Servicio de Cirugía Oral Maxilofacial e Implantología, Hospital Quirón, Barcelona

Plaza Alfonso Comín 5-7

Planta $4^{\mathrm{a}}$, despachos 423-424

08023 Barcelona, España

email: jgonzalez.bcn@quiron.es 


\section{Introducción}

El manejo quirúrgico del sector posterior del maxilar fue desde los comienzos de la implantología moderna un reto para el profesional. ${ }^{1}$ La mala calidad del hueso, reabsorciones extremas y la presencia de la cavidad del seno maxilar constituían obstáculos insalvables para la rehabilitación implantosoportada en ese sector. La introducción de la técnica de elevación de seno por Philip Boyne, ${ }^{2}$ a principios de los 80, fue rapidamente aceptada e implantada. En la actualidad la elevación de seno es probablemente la primera opción de tratamiento en el paciente tributario de rehabilitación con implantes en el maxilar posterior atrófico.

La elevación de seno maxilar ha demostrado ser una técnica fiable en el manejo de estos pacientes. Desgraciadamente esta técnica puede acompañarse de costes económicos superiores, mayor morbilidad y riesgo de sinusitis. Además, pueden concurrir determinadas circunstancias en el paciente o en el cirujano que desaconsejen la práctica del procedimiento.

Por su parte, el uso de implantes cortos (menos de $10 \mathrm{~mm}$ ) se ha asociado tradicionalmente con unas tasas de supervivencia menores que la de los implantes largos. Nos obstante la aparición de nuevas superficies y diseños indican que este tipo de implantes puede soportar de forma adecuada restauraciones dentales.

El empleo de implantes dentales cortos de una superficie porosa sinterizada es una alternativa simple y fiable, cuando exista alguna contraindicación a la elevación de seno. Presentamos la técnica de instalación de estos implantes, asi como una revisión actualizada sobre su uso.

\section{Técnica quirúrgica}

Se ha utilizado como ejemplo un sistema de implantes de superficie porosa sinterizada (Endopore, Dental Implant System, Innova Corporation, Toronto). Este tipo de superficie permite el crecimiento óseo hacia el interior de las rugosidades de la superficie del implante.

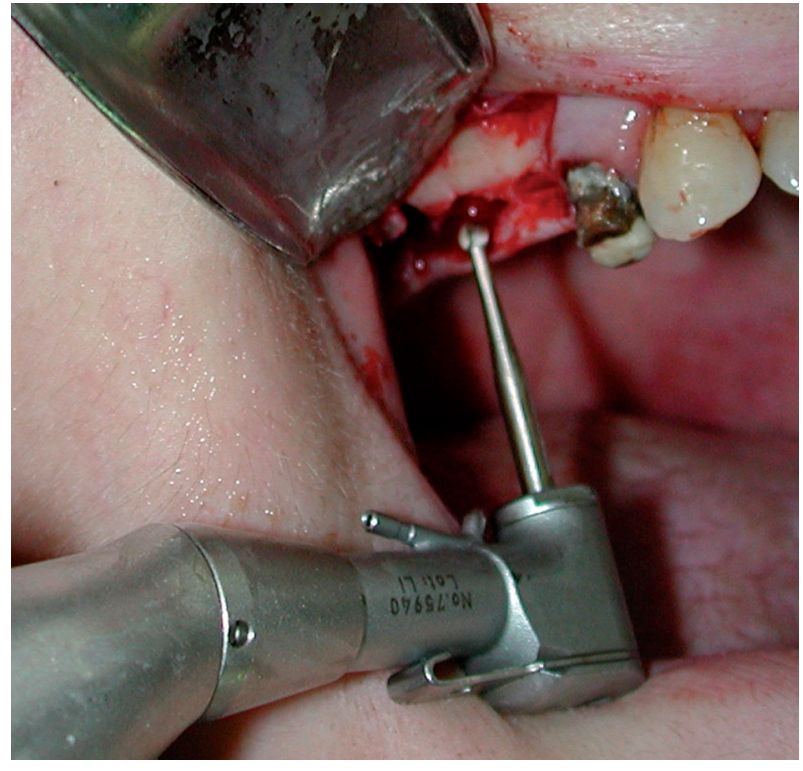

Figura 1. Elevación del colgajo mucoperióstico y empleo de la fresa de inicio.

Figure 1. Lifting of mucoperiosteal flap and use of starter drill.

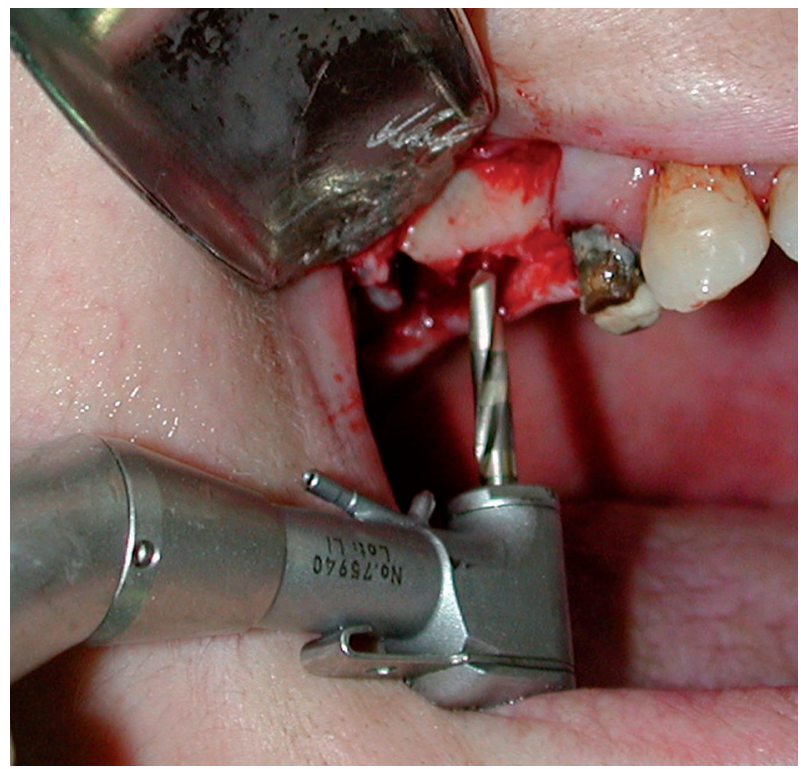

Figura 2. Fresa espiral de $2 \mathrm{~mm}$, introducida hasta el límite marcado por la posición del seno maxilar.

Figure 2. Two-millimeter spiral drill inserted to the limit marked by the position of the maxillary sinus.

\section{Introduction}

The surgical management of the posterior maxilla has challenged professionals since modern implantology began. ${ }^{1}$ Poor bone quality, extreme reabsorption, and the presence of the maxillary sinus cavity were insurmountable obstacles for implant-supported rehabilitation of the sector. The maxillary sinus elevation technique introduced by Philip Boyne 2 in the early 1980s was quickly accepted and integrated into practice. At present, sinus elevation is probably the first therapeutic option in candidates for implant rehabilitation of an atrophic posterior maxilla.

Maxillary sinus elevation has been shown to be a reliable technique in the management of these patients. Unfortunately it can be more expensive and accompanied by more morbidity and the risk of sinusitis. In addition, certain circumstances of the patient or surgeon may make the procedure inadvisable. On the other hand, short implants (less than $10 \mathrm{~mm}$ ) have been associated traditionally with lower survival rates than long implants. Nonetheless, the appearance of new surfaces and designs indicate that this type of implant can support dental restorations adequately.

The use of short dental implants with a sintered porous surface is a simple and reliable alternative when any contraindication against sinus elevation exists. We report the technique for placing these implants and update our review of their use.

\section{Surgical technique}

The model used is a system of sintered porous-surfaced implants (Endopore, Dental Implant System, Innova Corpo- 
Las figuras 1-11 muestran la secuencia quirúrgica de la instalación de este tipo de implantes.

\section{Discusión}

El sector posterior del maxilar reúne unas características anatómicas y morfológicas que complican la instalación de implantes dentales. La combinación de un volumen óseo deficitario, con una calidad ósea deficiente y una cavidad antral con frecuencia hiperneumatizada hacen que con frecuencia el cirujano deba recurrir a técnicas avanzadas. ${ }^{1,3}$

La elevación del seno para facilitar la colocación de implantes en el maxilar posterior atrófico fue introducida en 1980 por Philip Boyne. ${ }^{2}$ En la literatura se han publicado numerosos trabajos en los que se han utilizado diferentes abordajes, diferentes materiales de injertos e implantes de diferentes características de superficie. ${ }^{4-6}$

Aunque la elevación de seno suele ser la primera opción en el manejo del sector posterior del maxilar atrófico, ${ }^{4}$ existen una serie de condiciones (Tablas 1 y 2) que aconsejan recurrir a otros procedimientos.

\section{Implantes cortos}

En general, para obtener una retención primaria fiable se recomienda emplear implantes dentales de al menos $10 \mathrm{~mm}$ de longitud. Cuando se utilizan implantes de menor diámetro se habla de implantes cortos. Aunque se ha utilizado implantes roscados cortos con resultados aceptables, la introducción de los implantes sinterizados supuso una mejora considerable en los ratios de osteointegracíón. ${ }^{11-}$ ${ }^{13}$ Este tipo de implantes, de forma cónica y que se instalan con una técnica de impactación, pueden ser utilizados en zonas de dimensiones óseas limitadas debido al establecimiento de una interfase con el hueso circundante que permite el anclaje mecánico por crecimiento del hueso dentro de la superficie porosa sinterizada. Estas características hacen que incluso los implantes más cortos obtengan tasas de supervivencia elevadas.

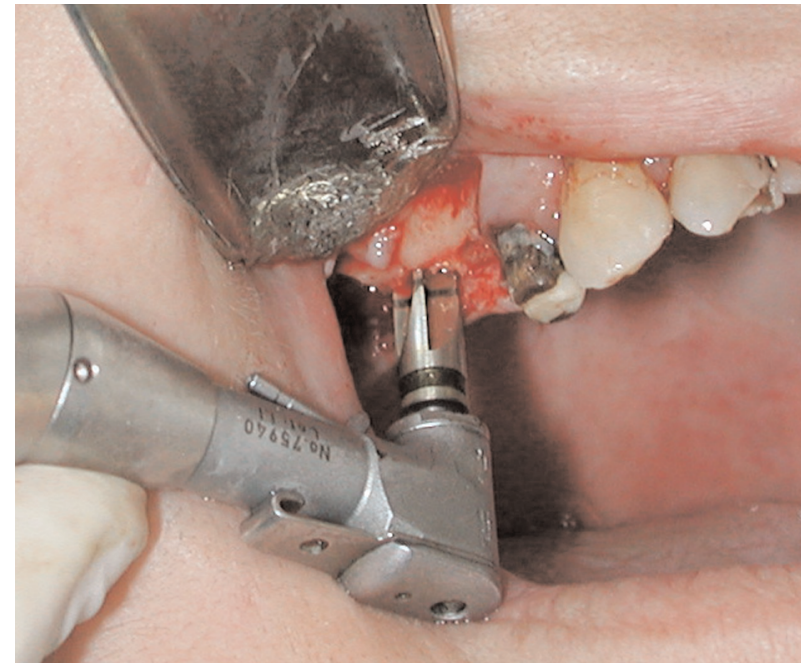

Figura 3. Se escoge la fresa específica para la longitud y diámetro del implante seleccionado.

Figure 3. A specific drill bit is chosen for the length and diameter of the implant selected.
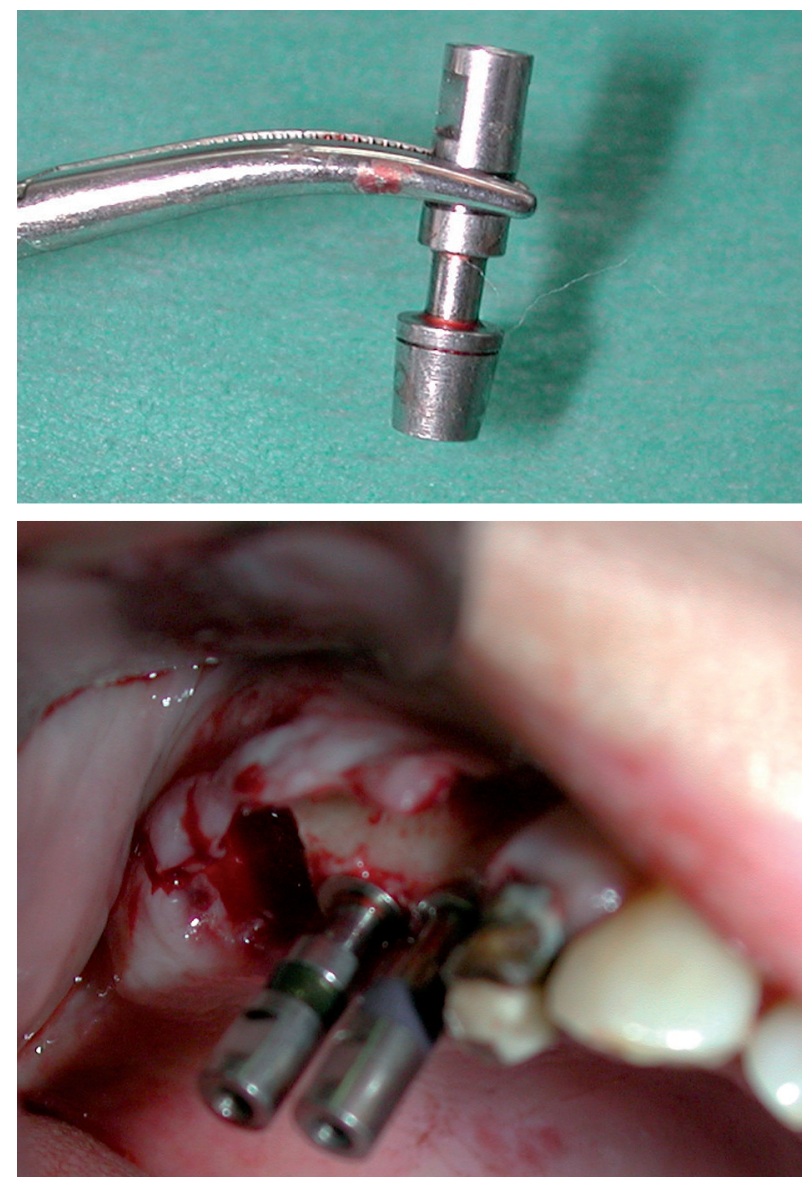

Figura 4. (a y b) Introducción de guía cuya estabilidad confirma la posibilidad de instalar el implante

Figure 4. ( $a$ and $b$ ). Introduction of a guide. The stability of the guide confirms the possibility of placing the implant. ration, Toronto, Canada). This type of surface allows bone ingrowth into the connecting pores of the implant surface.

Figures 1-7 show the surgical sequence of the placement of this type of implants.

\section{Discussion}

The posterior maxilla has anatomic and morphologic characteristics that complicate the placement of dental implants. The combination of reduced bone volume with deficient bone quality and a frequently hyperpneumatic antral cavity means that the surgeon often must resort to advanced techniques. ${ }^{1,3}$ Sinus elevation to facilitate implant placement in the atrophic posterior maxilla was introduced by Philip Boyne in 1980.2 Numerous studies have been published in the literature using different approaches, graft materials, and implants with a variety of surface characteristics. $^{4-6}$

Although sinus elevation usually is the first option in the management of atrophic posterior maxilla, ${ }^{4}$ a series of conditions exist (Tables 1 and 2) that make it necessary to resort to other procedures.

\section{Short implants}

In order to achieve reliable primary retention, the use of dental implants at least 10 $\mathrm{mm}$ long is generally recommended. When implants of less length are used, they are referred to as short implants. Threaded short 


\section{Implante cortos de superficie sinterizada}

El diseño del implante incluye una superficie porosa (grosor de 300 micras) compuesto de partículas esféricas de una aleación de titanio fijada al núcleo del implante mecanizado mediante sinterización a alta temperatura. Este proceso resulta en la formación de unos cuellos sinterizados, o regiones de unión entre las partículas esféricas individuales y entre partículas y el núcleo del implante. Este cuello asegura que la superficie porosa sea parte integral del implante, y no un simple recubrimiento. Se crea así una superficie que no solo aumenta la superficie de contacto, sino que permite el crecimiento óseo hacia el interior de la red porosa interconectada. 7,8

Este tipo de implantes tiene forma de cono truncado convergente hacia apical, y su instalación es mediante la técnica de impactación, tiene un cuello liso de 1-2 mm de altura y una zona porosa "sinterizada" a lo largo del resto del implante.

Los estudios efectuados sobre animales de los implantes de superficie sinterizada indican que si se cumplen unos requisitos quirúrgicos mínimos (evitar micro-movimientos en las fases iniciales, y la no exposición de la superficie sinterizada), ${ }^{9-11}$ estos implantes son igual de exitosos que los implantes roscados a pesar de la enorme facilidad de su colocación. ${ }^{12}$ Además, estos implantes podrían tener una menor longitud y desarrollar una fijación equivalente que implantes roscados de longitud equivalente. ${ }^{7}$

Los resultados de Deporter lo muestran. ${ }^{13-15}$ Así, en 2001 se instalaron 151 implantes en 50 pacientes, de los cuales el $76,8 \%$ se instalaron en el sector posterior del maxilar. La longitud media del implante fue de $8,7 \mathrm{~mm}$. A los 3 años la tasa de supervivencia fue del $97,3 \%$ (fracaso de 4 implantes) y todos los implantes habían sido cargados protésicamente

\section{Relación corona-raiz}

La relación corona-raiz se utiliza habitualmente en el diseño de prótesis dentosoportadas, debido al mecanismo de unión que supone el ligamento periodontal. Esta estruc-
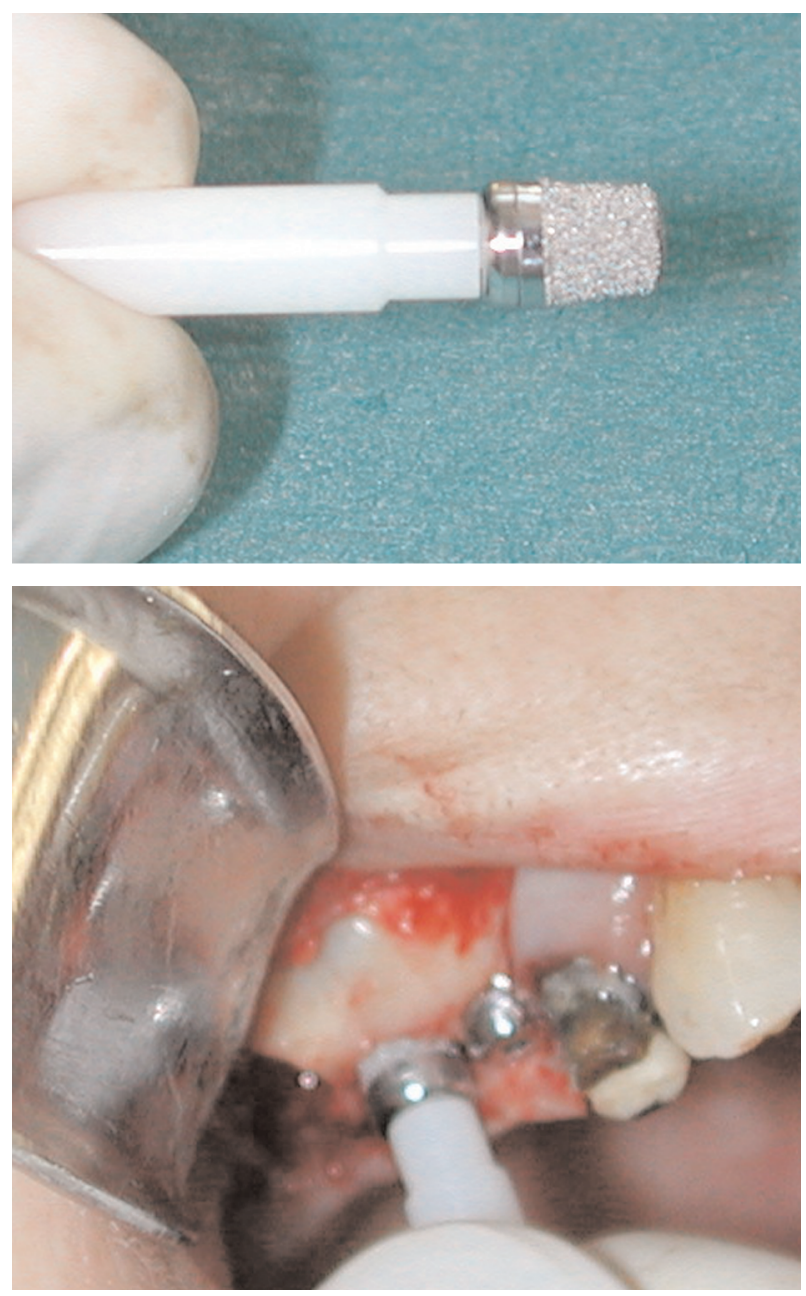

Figura 5. (a y b) Introducción del implante con su transportador de plástico

Figure 5. $(a$ and $b)$. Insertion of the implant with its plastic holder.

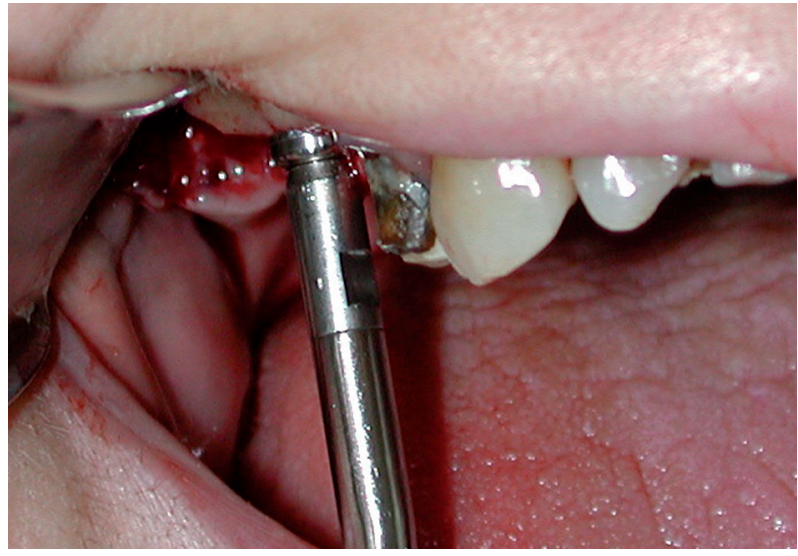

Figura 6. Instalación final del implante con escoplo acodado. Figure 6. Final placement of the implants with an angled chisel. implants have been used with acceptable results, but the introduction of sintered implants represented a considerable improvement in osseointegration ratios. ${ }^{11-13}$ This type of implants, which have a truncated cone shape and are placed using a pressin technique, can be used in areas of limited bone dimensions because an interface is established with the surrounding bone that allows mechanical anchorage by bone growth into the sintered porous surface. These characteristics mean that even short implants have high survival rates.

\section{Short sintered surface implants}

The design of the implant consists of a porous surface (300-micra thick) composed of spherical particles of a titanium alloy affixed to the machined implant nucleus by high-temperature sintering. This process results in the formation of sintered necks, or regions of union between the individual spherical particles and between the particles and implant core. This neck ensures that the porous surface is an integral part of the implants and not just a coating. This creates a surface that not only increases the contact surface, but encourages bone growth to penetrate the interconnected porous network. 7,8

This type of implants has the form of a truncated cone that narrows apically and it is placed by means of a press-in technique. The implant has a smooth neck 1-2 mm high and a sintered porous surface on the rest of the implant.

Studies conducted on animals of implants with a sintered surface indicate that if they meet minimal surgical 
tura elástica responde a las fuerzas oclusales y puede ser el origen de la movilidad dental, Se considera que una relación corona/raiz de 2/1 es la más adecuada para los dientes naturales. Este mismo principio se ha aplicado a los implantes roscados. ${ }^{16}$ No obstante, en un estudio reciente sobre 262 implantes cortos mecanizados con 53 meses de seguimiento, Tawill y cols. observaron que una relación corona/implante desfavorable no fue un factor de riesgo para el fracaso del implante, siempre que la orientación de fuerzas, la distribución de cargas y las parafunciones estén controladas. ${ }^{17}$

\section{Curación-reabsorción ósea}

Con el protocolo quirúrgico adecuado la superficie sinterizada promueve una rápida reparación ósea inicial. Simmons y cols. ${ }^{18}$ sugierieron la posibilidad de cargar estos implantes a las 5-6 semanas, aunque en general los tiempos estándar suelen ser de 4 meses en el maxilar y 3 en la mandíbula.

El patrón de remodelado óseo crestal se limita a la región lisa-mecanizada del implante, con una estabilización del hueso cerca de la unión entre el cuello y la región porosa del implante. ${ }^{19}$ Tras un año de función la pérdida ósea crestal media estaba por debajo de los 0,2 $\mathrm{mm}$. Entre los años 2 y 10, la pérdida media anual fue de 0,03 mm. ${ }^{19,20}$

\section{Implantes cortos roscados estándar}

En una comparación de la supervivencia de los implantes cortos mecanizados versus implantes con grabado ácido (Osseotite TM) se observó una diferencia de supervivencia entre implantes estándar y cortos de $7,1 \%$ para los primeros y del $0,7 \%$ para los segundos. ${ }^{20}$ Es decir, que la longitud del implante dejaba de ser clínicamente significativa para la supervivencia del implante, siempre que éste tuviera una superficie tratada.

Un estudio sobre 168 implantes de 8 $\mathrm{mm}$ de longitud y 6 de diámetro con recubrimiento de HA, observó un tasa de supervivencia del $100 \%$ con un seguimiento medio de 34,9 meses. ${ }^{21}$ Malo, ${ }^{22}$ por su parte, utiliza 408 implantes de $7 \mathrm{y}$

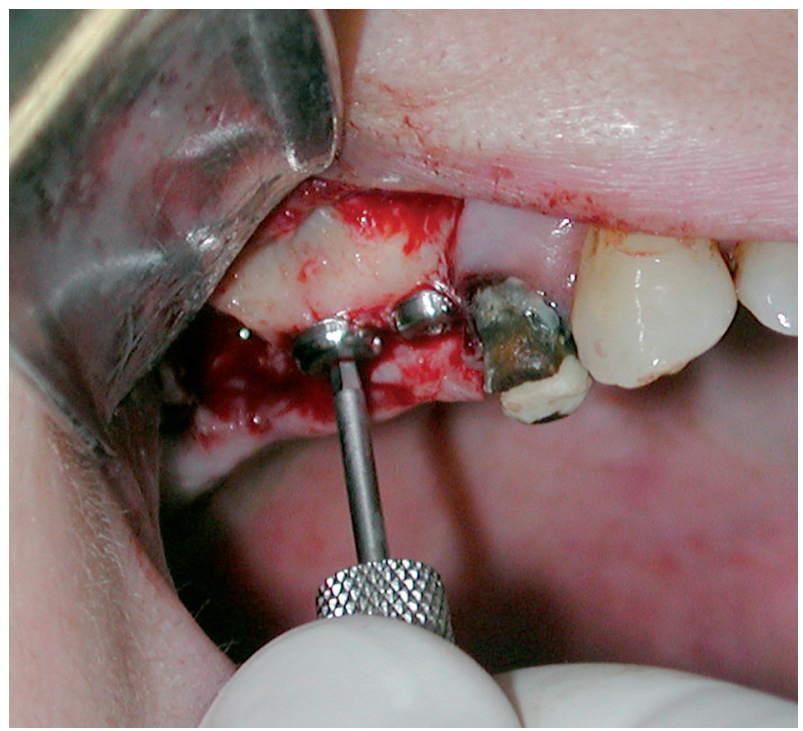

Figura 7. Instalación del tornillo de cierre. Figure 7. Placement of locking screw.

Tabla 1. Contraindicaciones médicas a la elevación del seno maxilar.

- Sinusitis aguda

- Alteraciones de la ventilación sinusal

- Lesiones ocupantes de espacio en el seno

- Consumo de drogas

- Radioterapia/quimioterapia

- Trastornos del sistema inmunitario

- Diabetes no controlada

Table 1. Medical contraindications to maxillarys sinus elevation.

- Acute sinusitis

- Alterations of sinus ventilation

- Space-occupying lesions of the sinus

- Drug use

- Radiotherapy/chemotherapy

- Immune system disorders

- Uncontrolled diabetes

Tabla 2. Otras contraindicaciones a la elevación del seno.

- Pacientes que no comprenden el procedimiento

- Pacientes que no quieren recibir ningún tipo de injerto

- Profesional que no quiere/sabe realizar el procedimiento

- Motivos económicos

Table 2. Other contraindications to sinus elevation.

- Patients who do not understand the procedure

- Patients who do not wish to receive any type of graft

- Professionals who do not wish or know how to perform the procedure

- Financial reasons requirements (avoidance of micro-movements in the initial phases and nonexposure of the sintered surface) $)^{9-11}$ they are as successful as threaded implants, despite the enormous ease of placement. ${ }^{12}$ In addition, these implants can have a smaller length while developing a fixation equivalent to threaded implants of equivalent length, ${ }^{7}$ as shown by the results of Deporter.13-15 In 2001, 151 implants were placed in 50 patients, of which $76.8 \%$ were placed in the posterior maxilla. The mean implant length was 8.7 $\mathrm{mm}$. At 3 years the survival rate was $97.3 \%$ (failure of 4 implants) and all the implants were loaded with prostheses.

\section{Crown-root ratio}

The crown-root ratio is used habitually in the design of tooth implant-supported prostheses, due to the binding mechanism of the periodontal ligament. This elastic structure responds to occlusal forces and may be the source of dental mobility. A crown/root ratio of 2/1 is considered to be the most suitable for natural teeth. The same principle has been applied to threaded implants. ${ }^{16}$ However, in a recent study of 262 machined short implants with 53 months of follow-up, Tawill et al. ${ }^{17}$ observed that an unfavorable crown/implant ratio was not a risk factor for implant failure, as long as the direction of the forces, load distribution, and .parafunctions are controlled.

Bone healing-reabsorption With the proper surgical protocol, the sintered surface 
$8,5 \mathrm{~mm}$ en 237 pacientes, con resultados a los 5 años del $96,2 \%$ y del $97,1 \%$.

En un estudio de carga inmediata en 133 implantes cotos se obtuvieron los mismos resultados de supervivencia $(97,7 \%)$ que en una técnica en dos fases. ${ }^{23}$

En una revisión de la literatura, ${ }^{24}$ se observó que el mayor fracaso de los implantes cortos se asociaba con la curva de aprendizaje del cirujano, una preparación no individualizada del lecho del implante, el empleo de implantes mecanizados, y la instalación en hueso de baja densidad. Cirujanos expertos, con una preparación customizada del lecho e instalación de implantes de superficie tratada pueden obtener resultados comparables a los obtenidos con implantes de longitud convencional. Se ha sugerido que la ferulización de los implantes, la restauración con una guía de oclusión canina y la selección de implantes que aumenten la superficie de contacto hueso-implante son factores importantes para aumentar la supervivencia de los implantes. ${ }^{25}$

\section{Alternativas a los implantes cortos}

Entre las alternativas sencillas figuran los implantes pterigoideos, los implantes inclinados ("tilted implants"), o la técnica "all on four" (Tabla 3).

Los implantes pterigoideos fueros introducidos por Tulasne, ${ }^{26}$ y su uso se fundamenta en el anclaje de los implantes a la base del cráneo, en concreto a las apófisis pterigoides del esfenoides, una estructura ósea que no presenta el fenómeno de reabsorción asociado con el edentulismo. Su instalación requiere el empleo de fresas largas, y unas inclinación látero-medial y caudo-craneal específicas, lo que hace que el procedimiento sea muy sensible a la técnica. La longitud mínima para un anclaje fiable es de $18 \mathrm{~mm}$. No obstante, se han descrito también los implantes de tuberosidad, y palatinos, con resultados aceptables. ${ }^{27}$ Tienen un alto índice de fiabilidad en los que se refiere a su osteo-integración. ${ }^{28-30}$

Los implantes inclinados fueron descritos por Aparicio. ${ }^{31}$ Se fundamentan en el anclaje de los implantes dentales allí donde existe hueso. Conceptualmente, se alejan de la implantología guiada por la prótesis, y retrotraen a la primera época de la

- Tilted implants
Tabla 3. Alternativas a la elevación del seno maxilar.

- Implantes cortos

- Implantes pterigoideos

- Implantes inclinados

- Técnica de "all on four"

- Técnicas de aumento

- Implantes zigomáticos

Table 3. Alternatives to maxillary sinus elevation.

- Short implants

- Pteygoid implants

- "All-on-four" technique

- Augmentation techniques

- Zygomatic implants

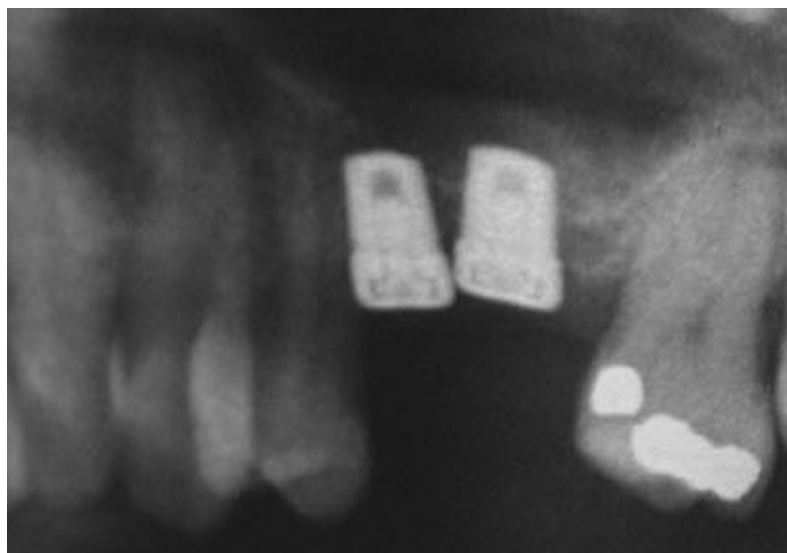

Figura 8. Rehabilitación de la cresta atrófica con dos implantes de $5 \times 5$ y elevación atraumática de seno.

Figure 8. Rehabilitation of atrophic crest with two $5 \mathrm{~mm} \times 5 \mathrm{~mm}$ implants and atraumatic sinus elevation.

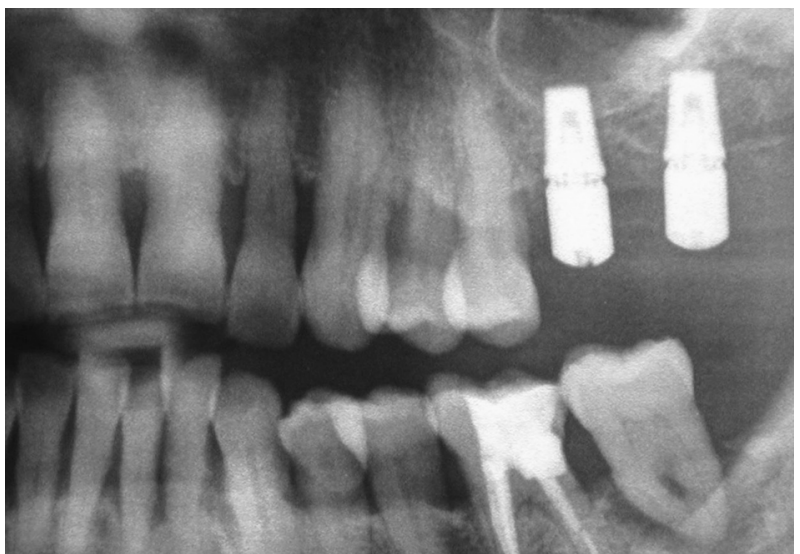

Figura 9. Rehabilitación con implantes de $7 \times 5$. Figure 9. Rehabilitation with $7 \mathrm{~mm} \times 5 \mathrm{~mm}$ implants. promotes rapid initial bone repair. Simmons et al. ${ }^{18}$ suggested that these implants could be loaded in 5-6 weeks, although the standard times are usually 4 months for the maxilla and 3 months for the mandible. The pattern of bone crest remodeling is confined to the smooth machined region of the implant, with stabilization of the bone near the union between the neck and the porous-surfaced region of the implant. ${ }^{19}$ After a year of function, mean crestal bone loss was less than $0.2 \mathrm{~mm}$. Between years 2 and 10, the mean annual bone loss was $0.03 \mathrm{~mm} .{ }^{19,20}$

\section{Standard threaded} easy-cut implants

In a comparison of the survival of short machined implants versus acid-etched implants (Osseotite ${ }^{T M}$ ), the difference in survival between standard and short implants was $7.1 \%$ for the machined implants and $0.7 \%$ for the acid-etched implants. ${ }^{20}$ This meant that the length of the implants was not clinically significant for implant survival, as long as the implant had a treated surface.

A study of 168 implants with a length of $8 \mathrm{~mm}$ and diameter of $6 \mathrm{~mm}$ coated with hydroxyapatite yielded a survival rate of $100 \%$ with a mean follow-up of 34.9 months. ${ }^{21}$ Malo ${ }^{22}$ used 408 implants of $7 \mathrm{~mm}$ and 8.5 $\mathrm{mm}$ in 237 patients, with a 5 -year survival of $96.2 \%$ and $97.1 \%$, respectively.

In a study of immediate loading on 133 short implants, the same survival results were obtained (97.7\%) as with a two-phase technique. ${ }^{23}$ 
implantología, cuando el cirujano instalaba los implantes sin considerar las necesidades prostéticas del paciente. No obstante, en pacientes seleccionados y suficientemente informados, puede ser una alternativa cuando el paciente no desea recibir ningún tipo de injerto.

La técnica "all on four" fue descrita por Malo, 32 y permite la rehabilitación del maxilar superior totalmente edéntulo con solamente 4 implantes. En consecuencia no es la mejor opción para rehabilitar de forma aislada el sector posterior maxilar.

Finalmente, existen otras técnicas de mayor complejidad para reconstruir el maxilar posterior atrófico sin recurrir a la elevación se seno, que incluyen los implantes cigomáticos, ${ }^{33}$ y los injertos en sándwich en el maxilar superior, ${ }^{34}$ cuya descripción se aleja de los objetivos de este artículo.

\section{Conclusiones}

Los implantes impactados de superficie rugosa sinterizada aportan versatilidad a la implantología dental. El empleo rutinario de implantes cortos (5 ó $7 \mathrm{~mm}$ ) en un hueso trabecular de baja densidad como el de la tuberosidad maxilar, ofrece unos resultados comparables a los implantes cilíndricos roscados. Sus ventajas incluyen una técnica quirúrgica de baja morbilidad, una rápida cicatrización ósea, la no necesidad de ferulización de las unidades protésicas se pueden utilizar en situaciones con relación corona-raiz desfavorables, y la pérdida ósea crestal durante la función es insignificante.

\section{Bibliografía}

1. Krogh P. Anatomic and surgical considerations in the use of osseointegrated implants in the posterior maxilla. Oral Maxillofac Surg Clin NA 1991;3:853-69.

2. Boyne PJ, James R. Grafting of the maxillary sinus floor with autogenous bone marrow and bone. J Oral Surg 1980;3:613-8.

3. Bahat O. Branemark system implants in the posterior maxilla: clinical study of 660 implants followed for 5 to 12 years. Int / Oral Maxillofac Implants 2000;15: 646-53.

4. Jensen OT, Shulman LB, Block MS, lacono VJ. Report of sinus graft consensus conference of Nov 16-17, 1996. J Oral Maxillofacial Implants 1998;13:11-32.

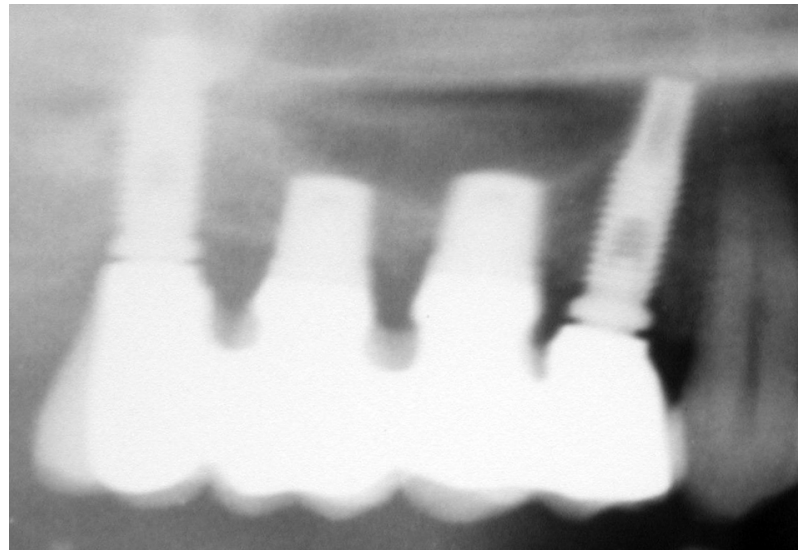

Figura 10. Combinación de diferentes técnicas;: implante estandar, implantes de $5 \times 5$ e implantes en tuberosidad.

Figure 10. Combination of different techniques: conventional implant, $5 \mathrm{~cm} \times 5 \mathrm{~cm}$ implants, and tuberosity implants.

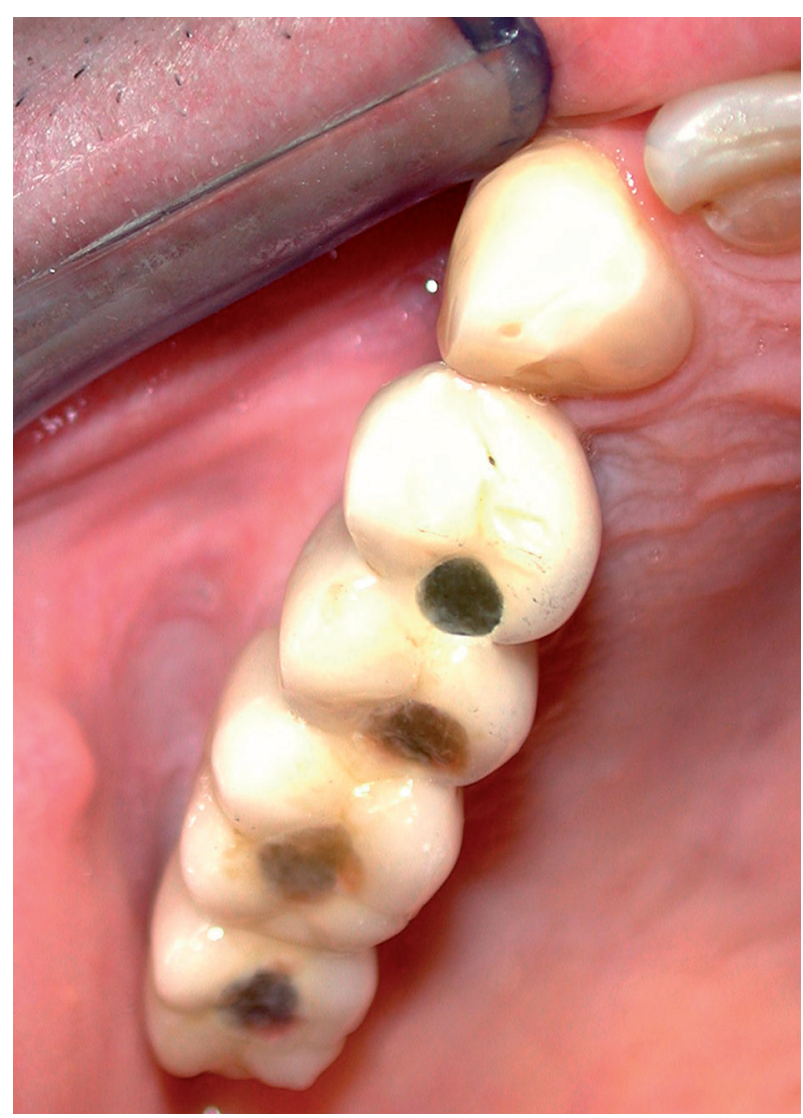

Figura 11. Imagen clínica del mismo caso.

Figure 11. Clinical image of the same case.
In a literature review, 24 it was observed that the higher rate of failure of short implants was associated with the learning curve of the surgeon, a non-individualized preparation of the implantation bed, the use of machined implants, and implantation in low density bone. Expert surgeons with customized preparation of the bed and placement of treated surface implants can obtain results comparable to those obtained with implants of conventional length. It has been suggested that splinting of implants, restoration with canine-protected occlusion, and the selection of implants that increase the bone-implant contact surface are important factors in increasing implant survival. ${ }^{25}$

\section{Alternatives \\ to short implants}

Among the simple alternatives are pterygoid implants, tilted implants, or the all-onfour technique (Table 3).

Pterygoid implants were introduced by Tulasne. ${ }^{26}$ Their use is based on anchoring implants to the skull base, specifically the sphenoid pterygoid process, a bone structure that does not present the phenomenon of reabsorption associated with the edentulism. Their implantation requires the use of long drills and specific latero-medial and caudo-cranial angling, which makes the procedure very sensitive to the technique. The minimum length for reliable anchorage is $18 \mathrm{~mm}$. However, tuberosity and palatine implants have been described with acceptable results. ${ }^{27}$ They have a high rate of reliability with regard to their osseointegration. ${ }^{28-30}$

Tilted implants were described by Aparicio. ${ }^{31}$ They are based on anchoring the dental implants where bone exists. Conceptually, they are distant from prosthesis-guided implan- 
5. Tripplet RGH. Schow Sr. Autologous bone grafts and endosseous implants: complementary techniques. J Oral Maxillofac Surg 1996;54:486-94.

6. Sinus Graft Consensus Conference. Academy of Osseointegration, Wellesley MA Nov 16-17, 1996. Int J Oral maxillofac Implamts 1998;13(suppl).

7. Pilliar RM. Dental implants:materials and design. / Canad Dent Assoc. 1990;56:85761.

8. Pilliar R M. Overview of surface variability of metallic endosseous dental implants: textured and porous surfaced structure designs. Implant Dent 1998;7:305-14.

9. Deporter DA Todescan N, Riley N. Porous surfaced dental implants in the partyially edentulous maxilla: assesment for subclinivcal mobility, Int J Periodontics Restorative Dent 2002;22:184-92.

10. Seller Al. Clinical evaluation of a porous surfaced endosseous implant system. J Oral Imp/ 1996; 22:240-6.

11. Deporter D, Watson PA, Pillar RM. A histological comparison in the dog of porous coated versus threaded dental implants. J Dent Res 1990;69:1138-45.

12. Deporter DA, Todescan R, Caudry S. Simplifying management of the posterior maxilla using short, porous surfaced dental implants and simultaneous indirect sinus elevation. Int / Periodontic Restorative Dent 2000;20:477-85.

13. Deporter DA, Todescan R, Watson PA, Pharoah M, Pillar RM, Riley N, Nardinit K. A prospective human clinical trial of the Endopore dental implant in restoring the partially edentulous maxilla using fixed prostheses. Int / Oral Maxillofac Implants 2001;16:527-36.

14. Deporter DA, Caudry S, Kernalli J, Adegbembo A. Further data on the predictability of the indirect sinus elevation procedure used with short sintered poroussurfaced dental implants. Int J Periodontics Restorative Dent 2005;25:585-93.

15. Deporter DA, Todescan R, Caudry S. Simplifyng management of the posterior maxilla using short porous-surfaced dental implants and simultaneous indirect sinus elevation. Int J Periodontics Restorative Dent 200;20:477-85.

16. Rokni S, Todescan R, Wtason P, Pharoah M, Adeghembo A, Deporter D. An assessment o crown to implant ratios with short sintered porous susfaced implants supporting prótesis in partially edentulos patients. Int J Oral Maxillofac Implants 2005;20:69-76.

17. Tawil G, Aboujaoude N, Younan R. Influence of prosthetic parameters on the survival and complication rates of short implants. Int / Oral Maxillofac Implants 2006;21:275-82.

18. Simmons C, Vaiqueette N, Pillar RM. Osseointegration of sintered porous surfaced and plasma spray.coated implants. An animal model study of early postimplantation healing response and mechanical stability. I Biomed Mater Res 199;47:127-38.

19. Levy D, Deporter DA, Pharoah M, Tomlinson G. A comparison of radiographic bone height and probing attachment level measurements adjacent to porous surfaced dental implants in humans. Int J Oral Maxillofac Implants 1997;12:541-6.

20. Feldman S, Boitel N, Weng D, Kohles SS, Stach RM. Five year distributions of short-lengh (10 mms or less) machined-surfaced and osseotite implants. Clin Implant Dent Relat Res 2004;6:16-23.

21. Griffin Tj, Cheung WS, The use od short wide implants in posterior areas with reduced bone heights: a retrospective investigation. J Prosthet Dent 2004;92:139-44.

22. Malo P. De Araujo, Ranget B. Short implants placed one stage in maxillae and mandibles: a retrospective clinical study with 1 to 9 years of follow up. Clin Implant Dent Relat Res 2007;9:15-21.

23. Degidi M, Piatelli A, lezzi G, Carinci F. Inmmediately loaded short implants: análisis of a cases series of 133 implants. Quintessence Int 2007;38:193-201.

24. Renouard F, Nisand D.Impact of implant length and diameter on survival rates. Clin Oral Implants Res 2006;17:35-51. tology and they are a throwback to the early stage of implantology, when the surgeon placed the implants without considering the prosthetic needs of the patient. However, in selected and sufficiently informed patients, tilted implants can be an alternative when the patient does not wish to undergo any type of graft.

The "all-on-four" technique was described by Malo32 and allows the rehabilitation of a completely edentulous upper maxilla with only 4 implants. Consequently, it is not the best option for the isolated rehabilitation of the posterior maxilla.

Finally, other, more complex, techniques exist for the reconstruction of the atrophic posterior maxilla without resorting to sinus elevation, including zygomatic implants ${ }^{33}$ and sandwich grafts of the upper jaw. ${ }^{34}$ However, the description of these techniques goes beyond the objectives of this article.

\section{Conclusions}

Sintered, rough surfaced implants that are placed by impaction offer versatility to dental implantology. The routine use of short implants ( $5 \mathrm{~mm}$ or $7 \mathrm{~mm}$ ) in low density trabecular bone like the maxillary tuberosity offers results comparable to those of threaded cylindrical implants. Their advantages include a surgical technique with low morbidity, rapid bone healing, the absence of any need for splinting prosthetic units can be used in situations with an unfavorable crown-root ratio. Crestal bone loss during function is insignificant. 
25. Misch CE, Steignga J, Barboza E, Misch-Dietsh F, Cianciola LJ, Kazor C. Short dental implants in posterior partial edentulism: a multicenter retrospective 6-year case series study. J Periodontol 2006;77:13407.

26. Tulasne JF. Osseointegrated fixtures in the pterygoid region. En Worthington P, Branemark PI: Advanced osseointegration surgery, applications in the maxillofacial region. Chicago: Quintessence Pub 1992; $182-8$.

27. Reiser GM. Implant use in the tuberosity, pterygoid and palatine region: anatomic and surgical considerations. En Nevins M, Mellonig JT. Implant therapy:clinical approaches and evidence of success. Chicago: Quintessence Pub 1998;197-208.

28. Raspall G, Gonzalez J, Bescós S Hueto JA. Pterigomaxillary osseointegrated fixture. J Craniomaxillofac Surg 1992;20:57-8.

29. Raspall G, Rodríguez X. Implantes pterigoideos RCOE 1998;3:461-7.
30. Rodríguez-Ciurana X. Rehabilitación del maxilar atrófico mediante implantes pterigoideos. Tesis Doctoral. Universitat Autónoma de Barcelona 2005.

31. Aparicio C, Perales P, Rangert B. Tilted implants as an alternative to maxillary sinus grafting: a clinical, radiologic and periotest study. Clin Implant Dent Relat Res 2001;3:39-49.

32. Malo $P$, Rangert B, Nobre M. All on 4 immediate-function concept with Branemark system implants for completely edentulous maxillae: a 1 year retrospective clincal study. Clin Implant Dent Rel Res 2005;7:8894.

33. Branemark PI, Zigoma fixture: clinical procedure. Goteborg, Suecia. Nobel Biocare 2000.

34. Keller EE, Van Roeckel NB, Desjardins RP, Tolman DE. Prosthetic reconstruction of the severely resorbed maxilla with iliac grafting and tissue integrated prostheses. Int J Oral Maxillofac Implants 1987;2:155-61. 